\title{
Getting around late protocol renewals
}

As always, time was running out for Ray Romansky. It was almost a game for him to wait until the eleventh hour before submitting his protocol renewal to the Great Eastern University IACUC. On some occasions he even had to secure a brief extension of time from the IACUC after the protocol had technically expired. So, true to form, he submitted his protocol the day it was due to expire, with a request to keep it active until the IACUC had time to review and approve it.

Naomi Gates was new to the IACUC office and was unaware of Romansky's history. She had been told that every protocol had an expiration date. Beginning 90 days before the expiration date, she sent monthly notices to investigators, reminding them to submit their protocols for renewal well before that date. Once a protocol expired, Gates's instructions were to inform the investigator that no further animal activities could occur until the protocol had been approved.
The following day after Romansky's protocol expired, Gates sent him a perfunctory 'cease and desist' notice, copying the animal facility to ensure that no additional animals could be ordered. Apparently, nobody had told Gates that the committee often flouted federal regulations and policy and allowed investigators to have some additional time before suspending animal activities on a protocol. When Romansky received the notice from Gates he became livid and immediately called the often-hassled Larry Covelli, the IACUC Chairman. Covelli was apologetic, but asked for Romansky's understanding. "The damage is done," Covelli told him, "and there's nothing I can really do."

Then Romansky got an idea. Because all of his protocols used the same basic methodology, he would transfer about 50 mice from his newly expired protocol to one of his active protocols. The 50 animals were less than 5\% of the approved number on the active protocol, so he believed it could be submitted as a minor amendment under Great Eastern's IACUC policy. He would just add them as an additional drug group to those already approved. Then he could continue his drug studies until the suspended protocol was approved, at which time he would transfer the animals back to that protocol. Covelli wanted to redeem himself, so he gave serious thought to Romansky's idea and concluded that he didn't know whether or not he had the authority to grant the request.

By not following federal regulations, the Great Eastern University IACUC seems to have boxed itself into a corner with Romansky. If not ethical, is Romansky's request even legal? If the request is approved by the IACUC as a minor amendment, is it compliant with federal policies to move animals out of a suspended protocol into an active one?

\section{RESPONSE}

\section{Still must submit}

\section{Kunwar K. Srivastava, DVM, PhD, DACVM}

It is clear that Romansky does not have any respect for the Great Eastern IACUC. He does whatever he likes irrespective of whether it is lawful or whether the IACUC agrees. Romansky has been lax in the past, as this is not the first time he has requested an extension of an expired protocol. Once his protocol expired, it was proper for the IACUC to send him a 'cease and desist' notice. After receiving that notice, Romansky was within his rights to call and talk with the IACUC Chair and request an extension of the expired protocol. However, Covelli was right to tell Romansky that he could not reverse the IACUC's decision.

Romansky's request to transfer the mice should be submitted to the IACUC in a protocol amendment and must secure approval before he can actually move the mice from his expired protocol to an active one. However, in approving the amendment and adding the mice to the active protocol-on which a certain number of animals were already approved by the IACUC_-Romansky should maintain the same total number of animals on that protocol by reducing the number of previously approved animals by the number of mice added. If Romansky secures approval of his amendment and adds the animals to the active protocol (reducing the number of animals in the active protocol as described above), then both Romansky and the IACUC will be in compliance with federal policies. If Romansky transfers mice from his expired protocol to the active protocol without securing prior approval from the Great Eastern IACUC, he will have committed scientific misconduct, which should be reported by Covelli to Great Eastern's Institutional Official.

Finally, it appears that the IACUC members and the investigators might want to refresh their training materials in order to comply with all the federal guidelines and avoid any such confusion in the future.

Srivastava is Professor and Attending Veterinarian, Tuskegee University, Tuskegee, AL. 